\title{
Analysis of Potentials and Strategies of Tourism Development at Mount Telomoyo
}

\author{
By: \\ Doriani Lingga \\ Faculty of Economics, Universitas Atma Jaya Yogyakarta \\ Email: doriani_lingga@staff.uajy.ac.id
}

\begin{abstract}
Mount Telomoyo does not only have agricultural potential, but also tourism potential. However, this potential has not been developed optimally. This research aimed to analyze the tourism potential at Mount Telomoyo and formulate its development strategies, so that it becomes a region with fast growing economy. The method used in this research was Delphi and AHP analysis methods in strategy formulation. The potentials of nature tourism at Mount Telomoyo are Sekar Langit Waterfall, Seloprojo Waterfall, Bleder Lake, and Andong Mountain Climbing. The cultural tourism includes Umbul Temple Hot Pool, Sunan Geseng Tomb, and the cultural events such as traditional ceremony/Tradition and People's Art. The locations of development priority were Seloprojo Tourism Area and Pandean Tourist Village. The development strategies of Telomoyo area as a global tourism included the construction of adequate road infrastructure, so that accessibility and mobility in Telomoyo area can run well. In addition, there was a need for the construction of supporting facilities and infrastructures, buildings and environmental arrangement, tourism and culture promotion using print and electronic media and involving stakeholders in the development and promotion, and socialization to the community about tourism
\end{abstract}

Keywords: Tourism, Potential, Strategy.

\begin{abstract}
ABSTRAK
Kawasan pegunungan Telomoyo tidak hanya memiliki potensi pertanian tetapi juga potensi pariwisata. Namun potensi ini belum dikembangkan secara maksimal. Penelitian ini bertujuan untuk menganalisis potensi pariwisata yang terdapat pada kawasan pegunungan Telomoyo dan merumuskan strategi pengembangannya sehingga menjadi kawasan dengan ekonomi yang cepat tumbuh. Metode yang digunakan adalah metode analisis Delphi dan AHP dalam perumusan strategi. Potensi wisata alam yang terdapat dikawasan Telomoyo adalah Air Terjun Sekar langit, Air Terjun Seloprojo, Telaga Bleder dan Pendakian Gunung Andong. Wisata Budayanya meliputi Pemandian Air Hangat Candi Umbul, Makam Sunan Geseng dan juga event budaya berupa Upacara Adat Istiadat/ Tradisi dan Kesenian Rakyat. Lokasi prioritas pengembangan yaitu Kawasan Pariwisata Seloprojo dan Kawasan Pariwisata Desa Pandean. Strategi pengembangan Kawasan Telomoyo sebagai kawasan pariwisata secara global ialah pembangunan infrastruktur jalan yang memadai sehingga aksesibilitas dan mobilitas di Kawasan Telomoyo dapat berjalan dengan baik. Selain itu, perlu adanya pembangunan sarana dan prasarana pendukung, penataan bangunan dan lingkungan, promosi pariwisata dan budaya dengan menggunakan media cetak dan elektronik dan melibatkan stakeholder dalam pengembangan dan promosi,serta sosialisasi terhadap masyarakat tentang pariwisata.
\end{abstract}

Kata Kunci: Pariwisata, Potensi, Strategi. 


\section{INTRODUCTION}

Magelang Regency, especially Ngablak Sub-District and Grabag Sub-District located in Telomoyo area rely on the agricultural sector as the driving force of the economy. The agricultural sector is the largest contributor of GRDP of Magelang Regency, which is 25.29 percent (BPS in 2013). These twosub-districts do not only have potentials of agropolitan and minapolitan areas, but also have a great potential of tourism area. However, the potential has not been developed optimally because it has not been supported by adequate facilities and infrastructure. The agricultural area in Magelang Regency has a wetland of 36,848 $\mathrm{Ha}$ and dry land of 42,568 $\mathrm{Ha}$. The dry land is 4,033 ha in Grabag sub-district and 1,672 ha in Ngablak sub-district. This becomes a potential agropolitan. Fisheries designated area has an area of 2,611 ha which has the potential to be a Minapolitan area covering fish pond area and rice field for rice-field farming. As for the tourism potential, there are Mount Telomoyo, Mount Andong, and cultural site of Umbul Temple.

Telomoyo area needs improvement and is expected to encourage the potential optimization to the surrounding areas, either agricultural potential to be an agricultural center, livestock potential to be minapolitan center, or tourism potential that has the opportunity to be developed into a national tourist attraction. Community participation is an important factor besides the role of government. According to Wearing (2001), the success of tourist village development will depend on acceptance level and support of local community. In addition, Timothy (1999) argues the importance of involving government, private sector, and other community members as stakeholders in deciding policies for the success of tourism development. Furthermore, he states that it is necessary to provide tourism education for local community with the aim to increase public knowledge, especially in the tourism benefits and to have awareness to maintain the sustainable tourism. Zhao, W., Ritchie, J., \& Echtner, C. M. (2011) state that the involvement of private sector also determines the success of a tourism area. This research aims to identify the tourism potentials of Mount Telomoyo. Furthermore, identification of the potentials and identification of internal factors (strengths and weaknesses) as well as external factors (opportunities and threats) are expected to form the basis of the development strategies of Mount Telomoyo as a tourist attraction. This research is motivated by the great tourism potential of Mount Telomoyo in the form of nature tourism consisting of waterfalls and mountain, cultural tourism in the form of temple and hot pool, and regular cultural events, such as traditional ceremony. Additionally, these potentials are supported by the development of agropolitan and minapolitan in Ngablak and Grabag sub-districts which become the attraction of Mount Telomoyo for both local and foreign tourists.

Pearce (1995) states that the development of a tourist village is a process of promoting the tourist village. In this case, the objective is to equip and improve the tourism facilities in order to meet the tourist needs. Several other researchers state that the development of tourism sector has a positive effect on the economy both directly or indirectly (Briedenhann \& Wickens, 2004; Chen \& Chiou-Wei, 2009; Croes \& Venegas, 2008; Holzner, 2011; Ma \& Hassink, 2013; Matarrita-Cascante, 2010; Tang \& Tan, 2015; Tugcu, 2014). Through intensive development process, Mount Telomoyo is expected to be the driving force of the economy of its hinderland area and encourages the surrounding area to become a fast growing area. Therefore, it is necessary to conduct a research related to tourism potentials at Mount Telomoyo and to identify problems related to development effort in the area. The development of tourism needs to be held gradually based on priority (Flora, Rickerl and Francis, 2004) and then to prepare its development strategies.

The objectives of this research are first, to determine the characteristics of the area, existing potentials and problems at Mount Telomoyo and its hinterland. The second is to determine the priority location in the development of Mount Telomoyo. The third is the formulation of plans and strategies for the development of Mount Telomoyo and its hinterland.

\section{ANALYTICAL METHOD}

In this research, data collection was performed by using primary and secondary data survey. Primary data collection was performed by conducting direct observation (field observation), unstructured and 
structured interviews using questionnaires, and direct measurement in the study area. Structured interview was conducted on experts and stakeholders to obtain factors in priority area formulation. Unstructured interview was conducted on local community to identify internal and external factors of the area. Secondary data collection was conducted by survey to related institutions, such as BPS, Bappeda, and departments related to the research, and using literature study.

The stage of literature study was conducted to collect data from libraries relevant to the problem. All literature related to factors in the development of Mount Telomoyo and the selection of priority location development were collected and then compiled in a questionnaire format to be distributed to experts.

The results of questionnaire were analyzed by weighting method (ranking) with AHP technique to obtain development factors and selection of priority location. Rating and scores are then be made to assess the development strategies and the priority location. Techniques of collecting information and the analysis method were performed through the following stages:

(1) Delphi Technique

Delphi analysis was conducted through interview with the respondents (relevant stakeholders) to explore opinions or information on appropriate and suitable criteria for use in determining development strategies and selection of priority location. The respondents in this research were experts from higher education institutions and stakeholders, namely Department of Public Work and Public Housing (PUPR) of Magelang Regency and heads of Grabag and Ngablak sub-districts.

(2) AHP Analysis

After obtaining criteria from delphi analysis, each criterion was weighted using AHP analysis. To run this analytical tool, an interview was conducted to the same stakeholders as in delphi analysis. The results obtained in the form of weights of each criterion were sorted to determine which criterion was the most priority.

Based on these criteria, eight selected villages in Telomoyo were identified its suitability. These villages were further analyzed to see which villages were in accordance with the criteria for determining the most in need-village for improvement in tourism development.

After obtaining the main criteria above the scale limits of "Important" and "Very Important", then a score was created for each criterion by dividing the weight of criterion by the total weights of all criteria. The results obtained in the form of score for each criterion were used as a guideline for area assessment by assuming that the total score was the maximum score of area assessment, which was 1000. After it was obtained the criteria of area assessment, then rating (ranking) and score were made to accomodate the condition of area in the field. Rating determination was adapted through literature review and applicable regulations.

To determine the development strategies of Mount Telomoyo, this research uses SWOT analysis. SWOT stages assume that an effective strategy is to maximize strengths and opportunities and minimize weaknesses and threats. External and internal factors form SWOT matrix (Karo karo,2006).

In this research, the steps of data analysis are as follows:

(1) Conducting data classification: to determine what factors are the strengths and weaknesses as internal factors of organization, and opportunities and threats as external factors of organization. This classification will generate SWOT information table.

(2) Conducting SWOT analysis: comparing by weighting between external factors of Opportunities and Threats and internal factors of Strengths and Weaknesses.

The results of SWOT analysis are then interpreted and developed into a decision of feasible strategy selection to be implemented. The selected strategy is generally the most likely outcome (most positive) with the lowest risks and threats. 


\section{RESULT AND DISCUSSION}

\section{Tourism potentials at Mount Telomoyo}

The tourism potentials at Mount Telomoyo based on RTRW of Magelang Regency are Ngablak and Grabag sub-districts located in Telomoyo area. Grabag sub-district has a primary function as a center for trade, agriculture, livestock and nature conservation.

Based on RTRW of Magelang Regency, there are two cultural preservation areas in Ngablak and Grabag sub-districts, namely Sunan Geseng Tomb and Umbul Temple. In addition, it is recorded that within RTRW of Magelang Regency, there dry land and wetland farming areas in Grabag and Ngablak sub-districts, namely fishery designated area directed to freshwater fishery in the form of Minapolitan Area in Grabag sub-district and natural tourism including Sekar Langit Waterfall and Bleder Lake.

In the Master Plan of Tourism Development of Magelang Regency in 2014-2034, both subdistricts are included in KSP B named as Pengembangan Sauja Alam "Lembah Merapi - Merbabu". The nature tourism located in Grabag and Ngablak sub-districts are Sekar Langit Waterfall, Seloprojo Waterfall, Bleder Lake and Andong Mountain Climbing. The cultural tourism are Umbul Temple Hot Pool and Sunan Geseng Tomb. There is a tourist village in the sub-district, namely Pagergunung tourist village. Various cultural events are held regularly in Ngablak and Grabag sub-districts, such as Traditional Ceremony/Tradition and People's Art.

Based on the result of survey to the field of tourism potential, there are two potentials that have not been included in the document of RTRW and RIPARDA of Magelang Regency, namely Joko Pekik Tomb and Andong Mountain Climbing in Girirejo Village.

\section{Priority Location}

In the effort to develop the tourism potentials at Mount Telomoyo, it is necessary to establish the main priority in accordance with predetermined criteria. Each criterion in determining this priority location is determined its weight based on priority scale. The most priority criterion will have the greatest weight, while least priority criterion will have small weight. Based on delphi analysis conducted by interview, it was generated the determinants of priority location, namely:

(1) Having handling urgency;

(2) Having contribution in handling issues in study area;

(3) Having contribution to the stimulation of regional growth and development in the study area;

(4) In accordance with regency growth and development policies;

(5) Having dominant issues related to the field of tourism development;

(6) Having dominant handling through the field of tourism development.

Weighting and scoring on existing factors and conditions generate total score and ranking. Location with highest total score is the main rank and is the top priority (Table 1).

The priority areas in the development of Mount Telomoyo in order are Seloprojo Tourism Area, Pandean Tourist Village, Kartoharjo Cultural Heritage Area, Tirto Cultural Heritage Area, Ngasinan Tourist Village, Girirejo Tourist Village, Pagergunung Tourist Village and Tlogorejo Tourist Village.

\section{Development Strategy}

Priority location of tourism development at Mount Telomoyo needs to be analyzed in more detail by conducting SWOT analysis. SWOT analysis was conducted by identifying internal and external factors of the region in its development. The factors affecting internal area were analyzed by collecting the data of all strengths and weaknesses. This data collection was performed by direct observation to the priority village and unstructured interview to the local people. As for the external factors of the region, opportunities data were collected, followed by threats data. After determining all factors of strengths, weaknesses, opportunities and threats, it can be formulated the strategies in the development of each region.

This research generates two types of strategy, namely the strategy covering all areas (main strategy) and the strategy of each regional development. The main strategy is the strategy required by each priority location, while the strategy of each regional development is adjusted to the 
conditions and needs of the area. The internal and external factors of each potential area are not the same, so that it requires different strategies.

\section{Seloprojo Tourism Development}

In addition to having a strategic location, the strengths of this area are the tourism potential of Seloprojo Waterfall and Mount Telomoyo, Mount Andong and Mount Merbabu sceneries seen from Seloprojo village surrounded by agricultural land and pine forest. Meanwhile, the weaknesses are poor road access and capacity, inadequate road infrastructure from main road to village, infamous tourism destination, and tourism potential that has not been developed optimally.

This tourism opportunities are that the area is potential to become a national tourist destination, can be integrated with the international tourism object of Borobudur Temple, can direct the tourism sector into economic driving sector in Seloprojo Village, and potentially becomes a fast growing area. Meanwhile, the threats are the conversion of agricultural land, weather uncertainty, and being densely populated and crowded village.

The strategies prepared by taking into account all mentioned factors are S-O strategy by developing tourism potentials, connecting tourism between Seloprojo Village and the surrounding tourism, W-O strategy by performing improvement on tourism access of Seloprojo Village, S-T strategy by conducting promotion, and $\mathrm{W}-\mathrm{T}$ strategy by enhancing the role of government in protecting farmers through agribusiness improvement policies.

\section{Pandean Tourist Village}

The internal factors of Pandean tourist village include strengths consisting of fertile agricultural land, superior commodity of vegetables, Telomoyo Mountain Climbing, and tourism potential of Mount Telomoyo, Mount Andong, and Mount Merbabu sceneries. Pandean village is included in the Tourism Strategic Area (KSP) and RIPARDA of Magelang Regency in 2014-2034. While the weaknesses include inadequate road capacity, poor access along the climbing path, Pandean village considered infamous tourist destination, and tourism potentials that have not been managed optimally.

The external factors as opportunities include the potential to become a national tourist destination, possible integration with the international tourism object of Borobudur Temple, directing the tourism sector as the economic driving sector in Pandean village, and having opportunity to become a fast growing area. The threats are the conversion of agricultural land and weather uncertainty as a consequence of the characteristic of nature tourism which is highly affected by weather.

The development strategies include S-O strategy by utilizing government authority to optimize existing resources, WO-strategy by increasing road capacity to Telomoyo, S-T strategy and settlement arrangement, $\mathrm{W}-\mathrm{T}$ strategy by improving facilities and infrastructure of the settlement.

\section{Kartoharjo Cultural Heritage Area}

The internal factors of Kartoharjo cultural heritage in terms of strengths include the tourism potentials of Umbul Temple, Umbul Temple hot pool, integration with the surrounding tourism potential, agricultural land surrounding the village, strategic location, quiet and calm environment, a heritage site. Moreover, Kartoharjo has been included as as a Tourism Strategic Area (KSP) in RIPARDA of Magelang Regency in 2014-2034, and is included a Heritage Area in RTRW of Magelang Regency. While the weaknesses include inadequate road capacity, the area considered infamous tourist destination, the development of hot pool that has not been optimal and the poor condition of the pool.

The external factors of Kartoharjo Cultural Heritage in terms of opportunities include the potential as a national tourist destination and possible integration with the surrounding tourist destinations. The main challenge is that the village will be more densely populated and crowded.

The development strategies include S-O strategy by developing tourism and agriculture sectors as potential sectors, utilizing government authority to optimize existing resources, W-O strategy of pool restoration and exterior decoration of Umbul Temple hot pool area, S-T strategy by promoting 
Umbul Temple hot pool to attract visitors, and W-T strategy by improving and existing facilities and infrastructure and providing new facilities and infrastructure.

\section{Tirto Cultural Heritage Area}

The internal factors as the strengths of Tirto Cultural Heritage Area include religious tourism of Sunan Geseng tomb, the tourism potential of Mount Telomoyo, Mount Andong and Mount Merbabu sceneries and strategic location. While the weaknesses include inadequate road capacity, the village that has not been known as a religious tourism, and the tourism that has not been developed optimally. The external factors as the opportunities are its potential as a national tourist destination and possible integration with international tourist destination of Borobudur Temple. The challenges are the conversion of agricultural land and weather uncertainty.

The development strategies of this area include S-O strategy by developing potential sectors, which is tourism sector and utilizating government authority to optimize existing resources, W-O strategy by providing information board on History of Sunan Geseng, W-O strategy by promoting Sunan Geseng tomb to attract visitors, W-T strategy by improving existing facilities and infrastructure and providing new facilities and infrastructure.

\section{Ngasinan Tourist Village}

The internal factors as the strengths of Ngasinan tourist village include water tourism of Bleder Lake, this area is included in Tourism Strategic Area (KSP) in RIPARDA of Magelang Regency in 2014-2034 and is included in Cultivation Area in RTRW of Magelang Regency. The weaknesses include inadequate road capacity, the village considered infamous tourist destination and tourism potential that has not been developed optimally.

The opportunities are that the village is potential to become a national tourist destination and can be integrated with international tourist destination of Borobudur Temple. The challenges include the conversion of agricultural land, weather uncertainty, and the possibility of the village to be more densely populated and crowded.

The development strategies are to develop the potential sectors of tourism and agriculture sectors, establishing relationship with private sector in investment, increasing the role of government in protecting farmers through agribusiness improvement policies, conducting a promotion on the potential area to attract investors and improving the tourism facilities and infrastructure.

\section{Girirejo Tourist Village}

The strengths of Girirejo Village include the tourism potentials of Ki Joko Pekik tomb cultural heritage, Andong Mountain Climbing, and Mount Telomoyo, Mount Andong and Mount Merbabu sceneries. The main weaknesses are inadequate road capacity, the area considered infamous tourist destination, and tourism potential that has not been developed optimally.

The opportunities are that the area is potential to be developed as a national tourist destination and can be integrated with international tourist destination of Borobudur Temple. The challenges are the conversion of agricultural land, weather uncertainty and the issue of community unreadiness.

The development strategies include the development of tourism sector as a potential sector, the utilization of government authority to optimize existing resources, road access improvement, promotion of Andong Mountain Climbing and Ki Joko Pekik tomb and improvement to existing facilities and infrastructure.

\section{Pagergunung Tourist Village}

The internal factors as the strengths of Pagergunung Village include its position surrounded by agricultural land, and the existence of periodic harvest festival as well as the tourism potential of Mount Telomoyo, Mount Andong and Mount Merbabu sceneries. The weaknesses include inadequate road capacity and the potentials that have not been supported by tourism facilities, such as lodging and public toilets. In terms of external factors, Pagergunung Village has the opportunity to 
be a national tourist destination. The most important development strategy is the utilization of government authority to optimize the existing resources.

\section{Tlogorejo Tourist Village}

The internal factors as the strengths of Tlogorejo Village include the tourism potentials of Sekar Langit Waterfall, Mount Telomoyo, Mount Andong and Mount Merbabu sceneries. This village has been recorded as a Heritage Area in RTRW of Magelang Regency. Meanwhile, the weaknesses of this village include inadequate road capacity and infamous tourist destination. The external factor as the opportunity is the potential to become a national tourist destination. The external factors as the challenges of village development are the conversion of agricultural land and community unreadiness. The development strategies include the tourism potential development of Sekar Langit Waterfall, connecting between Sekar Langit Waterfall tourism and the surrounding tourism, and making improvement to access of Sekar Langit Waterfall.

Ideally, every tourist destination is connected to one another. Thus, Telomoyo Area will become a major tourist destination. In an effort to connect the tourist village into a tourism area, the main strategy of Telomoyo area development is to construct adequate road infrastructure, so that the accessibility and mobility in Telomoyo Area can run well. In addition, it is necessary to provide supporting facilities and infrastructure, such as visitor information center, public toilets, garbage bins and other facilities, building and environmental arrangement, tourism and cultural promotion by using print and electronic media and involving stakeholders (for example, travel agency), conducting festival/harvest party with bazaar regularly, and conducting socialization to the community about tourism.

\section{CONCLUSION}

The tourism potentials at Mount Telomoyo include Sekar Langit Waterfall, Seloprojo Waterfall, Bleder Lake and Andong Mountain Climbing. The cultural tourism includes Umbul Temple Hot Pool, Sunan Geseng Tomb and Ki Djoko Pekik Tomb. The existing tourist village is Pagergunung village, while the cultural events in Ngablak and Grabag sub-districts are Traditional Ceremony/Tradition and People's Art.

The priority development areas in order are Seloprojo Tourism Area, Pandean Tourist Village, Kartoharjo Cultural Heritage Area, Tirto Cultural Heritage Area, Ngasinan Tourist Village, Girirejo Tourist Village, Pagergunung Tourist Village and Tlogorejo Tourist Village.

Each of these villages is ideally interconnected. Thus, Mount Telomoyo will become a major tourist destination. The development strategies of Mount Telomoyo consist of main strategy needed by each village and the development strategy adjusted to the needs of each village. The development strategies of Mount Telomoyo as a global tourism area include the construction of road infrastructure, provision of supporting facilities and infrastructure such as visitor information center, public toilets and garbage bins, building and environmental arrangement, tourism and culture promotion by using print and electronic media and involving stakeholders in promotions (for example, travel agency), conducting festival/harvest party with bazaar regularly, and conducting socialization to the community about tourism..

\section{REFERENCES}

Briedenhann, J., and Wickens, E. (2004). Tourism Routes as a Tool for the Economic Development of Rural Areas: Vibrant Hope or Impossible Dream? Tourism Management, 25 (1) , 71-79.

Chen, C.F., and Chiou-Wei, S. (2009). Tourism Expansion, Tourism Uncertainty and Economic Growth: New Evidence from Taiwan and Korea. Tourism Management, 30 (6), 812-818.

Croes, R., and Venegas, M. (2008). Cointegration and Causality between Tourism and Poverty Reduction. Journal of Travel Research, 47 (1), 94-103. 
Flora, C. B., Rickerl, D., \& Francis, C. (2004). Community Dynamics and Social Capital. Agroecosystems Analysis, 43 (1), 93-107.

Pearce, D. (1995). Tourism a Community Approach $2^{\text {nd }}$ Edition. Harlow Longman.

Tang, C., and Tan, E. (2015). Does Tourism Effectively Stimulate Malaysia's Economic Growth? Tourism Management, 46(1), 158-163.

Timothy, D. J. (1999). Participatory Planning a View of Tourism in Indonesia. Annals of Tourism Research, 26 (2), 371-391.

Wearing, S.L. and Donald, Mc. (2002). the Development of Community Based Tourism: Re-Thinking the Relationship between Tour Operators and Development Agents as Intermediaries in Rural and Isolated Area Communities. Journal of Sustainable Tourism, 10 (3), 191-206.

Zhao, W., Ritchie, J., and Echtner, C. M. (2011). Social Capital and Tourism Entrepreneurship. Annals of Tourism Research, 38 (4), 157-1593.

\section{TABLES/FIGURE/GRAPH/CHART}

Table 1. Total Score and Ranking

\begin{tabular}{|c|c|c|c|c|c|c|c|c|c|c|c|c|c|c|c|c|c|c|c|}
\hline \multirow{2}{*}{ No. } & \multirow{2}{*}{ Criteria } & \multirow{2}{*}{ Indicators } & \multirow{2}{*}{ Weight } & \multicolumn{2}{|c|}{ Tirto Village } & \multicolumn{2}{|c|}{ Kartoharjo Village } & \multicolumn{2}{|c|}{ Pandean Village } & \multicolumn{2}{|c|}{ Ngasinan Village } & \multicolumn{2}{|c|}{ Seloprojo } & \multicolumn{2}{|c|}{ Pagergunung } & \multicolumn{2}{|c|}{ Girirejo } & \multicolumn{2}{|c|}{ Telogorejo } \\
\hline & & & & Value & Score & Value & Score & Value & Score & Value & Score & Value & Score & Value & Score & Value & Score & Value & Score \\
\hline \multirow{2}{*}{1} & \multirow{2}{*}{$\begin{array}{l}\text { Having } \\
\text { urgent } \\
\text { handling; }\end{array}$} & $\begin{array}{l}\text { The condition } \\
\text { of problems in } \\
\text { the area }\end{array}$ & 0.15 & 3 & 0.45 & 4 & 0.6 & 3 & 0.45 & 2 & 0.3 & 3 & 0.45 & 3 & 0.45 & 1 & 0.15 & 3 & 0.45 \\
\hline & & $\begin{array}{l}\text { The need for } \\
\text { control of a } \\
\text { fast growing } \\
\text { area }\end{array}$ & 0.15 & 3 & 0.45 & 3 & 0.45 & 3 & 0.45 & 2 & 0.3 & 3 & 0.45 & 3 & 0.45 & 3 & 0.45 & 3 & 0.45 \\
\hline 2 & $\begin{array}{l}\text { Having } \\
\text { contribution } \\
\text { in handling } \\
\text { problems in } \\
\text { study area; }\end{array}$ & $\begin{array}{l}\text { Impact on } \\
\text { tourism } \\
\text { development }\end{array}$ & 0.25 & 2 & 0.5 & 3 & 0.75 & 4 & 1 & 3 & 0.75 & 4 & 1 & 3 & 0.75 & 3 & 0.75 & 2 & 0.5 \\
\hline \multirow[t]{2}{*}{3} & \multirow{2}{*}{$\begin{array}{l}\text { Having } \\
\text { contribution } \\
\text { in the } \\
\text { stimulation } \\
\text { of regional } \\
\text { growth and } \\
\text { development } \\
\text { in the study } \\
\text { area; }\end{array}$} & $\begin{array}{l}\text { The strategic } \\
\text { location of the } \\
\text { area in the } \\
\text { regency } \\
\text { structure }\end{array}$ & 0.27 & 3 & 0.82 & 3 & 0.82 & 4 & 1.1 & 3 & 0.82 & 4 & 1.1 & 3 & 0.82 & 3 & 0.82 & 3 & 0.82 \\
\hline & & $\begin{array}{l}\text { The strategic } \\
\text { function of the } \\
\text { area in the } \\
\text { regency }\end{array}$ & 0.27 & 4 & 1.1 & 4 & 1.1 & 3 & 0.82 & 4 & 1.1 & 4 & 1.1 & 4 & 1.1 & 4 & 1.1 & 4 & 1.1 \\
\hline \multirow{2}{*}{4} & \multirow{2}{*}{$\begin{array}{l}\text { In accordance } \\
\text { with regency } \\
\text { growth and } \\
\text { development } \\
\text { policies; }\end{array}$} & $\begin{array}{l}\text { In accordance } \\
\text { with RTRW }\end{array}$ & 0.25 & 4 & 1 & 4 & 1 & 3 & 0.75 & 4 & 1 & 4 & 1 & 2 & 0.5 & 4 & 1 & 4 & 1 \\
\hline & & $\begin{array}{l}\text { In accordance } \\
\text { with RIPARDA }\end{array}$ & 0.25 & 4 & 1 & 4 & 1 & 4 & 1 & 4 & 1 & 4 & 1 & 4 & 1 & 4 & 1 & 4 & 1 \\
\hline \multirow{5}{*}{5} & \multirow{5}{*}{$\begin{array}{l}\text { Dominant } \\
\text { issues in } \\
\text { tourism }\end{array}$} & $\begin{array}{l}\text { Dominant issue } \\
\text { of tourism } \\
\text { facilities }\end{array}$ & 0.11 & 1 & 0.11 & 2 & 0.22 & 4 & 0.44 & 2 & 0.22 & 3 & 0.33 & 1 & 0.11 & 1 & 0.11 & 1 & 0.11 \\
\hline & & $\begin{array}{l}\text { Dominant issue } \\
\text { of clean water } \\
\text { sector }\end{array}$ & 0.11 & 1 & 0.11 & 1 & 0.11 & 3 & 0.33 & 1 & 0.11 & 2 & 0.22 & 1 & 0.11 & 1 & 0.11 & 1 & 0.11 \\
\hline & & $\begin{array}{l}\text { Dominant issue } \\
\text { of supporting } \\
\text { facilities and } \\
\text { infrastructure }\end{array}$ & 0.11 & 4 & 0.44 & 3 & 0.33 & 2 & 0.22 & 4 & 0.44 & 3 & 0.33 & 4 & 0.44 & 3 & 0.33 & 2 & 0.22 \\
\hline & & $\begin{array}{l}\text { Dominant issue } \\
\text { of garbage }\end{array}$ & 0.11 & 4 & 0.44 & 3 & 0.33 & 3 & 0.33 & 4 & 0.44 & 3 & 0.33 & 4 & 0.44 & 4 & 0.44 & 2 & 0.22 \\
\hline & & $\begin{array}{l}\text { Dominant issue } \\
\text { of road } \\
\text { infrastructure }\end{array}$ & 0.11 & 4 & 0.44 & 4 & 0.44 & 3 & 0.33 & 3 & 0.33 & 4 & 0.44 & 4 & 0.44 & 4 & 0.44 & 3 & 0.33 \\
\hline \multicolumn{2}{|c|}{ Total Score } & & & & 6.86 & & 7.15 & & 7.22 & & 6.81 & & 7.75 & & 6.62 & & 6.71 & & 6.31 \\
\hline \multicolumn{2}{|c|}{ Order } & & & & 4 & & 3 & & 2 & & 5 & & 1 & & 7 & & 6 & & 8 \\
\hline
\end{tabular}

